\title{
Göç Yaşamış 6. Sınıf Öğrencileri’nin Noktalama İşaretlerini Uygulama Düzeylerinin Toplum Dil Bilimi Açısından Íncelenmesi
}

\author{
Analyzing in Sociolinguistics of Applying Levels of Writing Rules and \\ Punctuation Marks of Middle School $6^{\text {th }}$ Grade Students Who had Migrated
}

\begin{abstract}
Gülece METIN*
Mehmet CANBULAT ${ }^{* *}$

Özet: Bu araştırmanın amacı Kocaeli/Körfez'e göç ile gelmiş ilköğretim 6. sınıf öğrencilerin noktalama işaretlerini uygulama düzeylerini tespit etmek ve tespit edilen sonucu toplum dil bilimi ilkeleri ile değerlendirmektir. Nitel bir çalışma olan bu araştırmanın katılımcıları 2010-2011 Eğitim-Öğretim Yılı'nda Körfez'de bulunan 4 ilköğretim okulunda 6. sınıfta okuyan 214 öğrencidir. Araştırmanın alt problemleri, Göç yaşamış öğrencilerin; a) Noktalama işaretlerini uygulama düzeyleri nedir? b) Noktalama işaretlerini uygulama düzeyleri ile anne, baba eğitim durumları arasında anlamlı fark var mıdır? şeklinde belirlenmiştir. Belirlenen bu alt problemleri ölçmek için Karabuğa (2011) tarafından geliştirilen "Noktalama İşaretlerini Değerlendirme Ölçeği” kullanılmıştır. Öğrenci velilerinin eğitim durumlarına ilişkin bilgiler veli bilgi formlarından alınmıştır. Belirtilen ölçeklere göre incelenen veriler IBM SPSS 20,0 programı ile çözümlenmiştir. Çıkarılan tablolar yorumlanmış ve göçe bağlı olarak anne-baba eğitim seviyesi düşük olan öğrencilerin noktalama işaretlerini uygulama düzeylerinin de düşük olduğu tespit edilmiştir. Tespit edilen sonuçlar toplum dil bilimi ilkeleri açısından değerlendirilmiştir. Araştırmanın sonunda mevcut durumun iyileştirilmesi konusunda sorumluluk alması gereken her makama uygun öneriler bulunulmuştur.
\end{abstract}

Anahtar Sözcükler: Göç, anne-baba eğitim seviyesi, noktalama işaretleri, toplum dil bilimi

Abstract: The purpose of this study is to find out about middle school $6^{\text {th }}$ grade students who had come to Kocaeli/Körfez through migration and how capable they are of using punctuation marks and to evaluate the results on socio-linguistics principles. The participants in this qualitative research were $2146^{\text {th }}$ grade students of the fourth middle school in Körfez in the 2010 to 2011 education year. Main goals of the study: Of those students who had migrated; a) What was the level reached in the correct application of punctuation marks? b) Whether there is any meaningful difference between applying punctuation marks and the educational level of their parents. The evaluation table that had been developed by Karabuga in 2011 for measuring punctuation marks has been used. Information about the students' parents' education level was collected from parent information forms. The results were examined according to the mentioned scales and were analysed with IBM SPSS 20.0 (Statistic Package for Social Science) program. Evaluation charts were commented upon, the results that were obtained were evaluated on socio-linguistics principles. At the end of this study and research some recommendations were seen as necessary for every office and the departments involved in this educational field so that we would be able to improve upon the present situation.

Keywords: Migration, educational level of parents, punctuation, sociolinguistics

\footnotetext{
* Öğr. Gör. Ege Üniversitesi, Eğitim Fakültesi, Türkçe Eğitimi Bölümü, İzmir, gulece.metin@ege.edu.tr

** Doç. Dr., Abant İzzet Baysal Üniversitesi, Eğitim Fakültesi, Bolu, canbulatm@gmail.com

Bu çalışma Gülece Metin'in Yüksek Lisans Tezi’nin yeniden ele alınmış halidir.
} 


\section{GíRiş}

Dil, insandan başka birçok canlının iletişim kurmak için farklı şekillerde kullandığı bir yetidir. İnsanı diğer varlıklardan ayıran ise dili kullanma şeklidir. Chomsky'nin ifade ettiği gibi sınırlı sayıda sözcük ve kuralla sınırsız sayıda ve duruma uygun cümle üretebilme yeteneğidir. İnsan kendini ifade etmek ve dış dünya ile bilgi alışverişinde bulunmak için dili kullanır. Dil sayesinde kültür aktarımı, toplumsallaşma, iletişim kurma gibi birçok toplumsal olay meydana gelir. Çeşitli toplumsal süreçlerin kaynağı olan dili yazılı ve sözlü olarak iki gruba ayırabiliriz. Sözlü dil, dilin en çok kullanılan şekli olsa da dile şeklini veren, onu belli kurallara bağlayan ve sistematik bir yapı haline getiren yazılı dildir. Yazı, dili görünür hale getiren yapıdır.

Noktalama işaretleri ise adeta yazıyı hedefe taşıyan yol işaretleri gibidir. Akalın, et alii $(2001,263)$ noktalama işaretlerinin önemini "Yazı, söyleneni aktarmada yeterli değildir. Konuşmadaki vurgu, ezgi ve duraklamalar da söyleneni anlamakta yardımci olurlar. Bu eksiklikleri bir derece de olsa tamamlamak için, noktalama işaretleri kullanılır" şeklinde açıklar. Türk Dil Kurumu'nun yayımladığ 1 Yazım Kılavuzu'nda $(2009,32)$ ise "Duygu ve düşünceleri daha açık ifade etmek, cümlenin yapısın ve duraklama noktaların belirlemek, okumayı ve anlamayı kolaylaştırmak, sözün vurgu ve ton gibi özelliklerini belirtmek üzere noktalama işaretleri kullantlır" ifadesi noktalama işaretlerinin konuşma ve yazma üzerindeki etkisini açıkça anlatmaktadır.

Yazılı anlatımda noktalama işaretlerinin öğretimi büyük önem taşımasına rağmen ilköğretimin $6,7,8$. sınıflarında yazılı anlatım çalışmaları için ayrı bir ders saati konulmamıştır. Bu çalışmalar Türkçe öğretiminin öğrenme alanları içinde bütünleşik olarak işlenmektedir. Yapılan tüm çalışmalara rağmen noktalama konusu ülkemizde her kademedeki öğrencilerin çoğunun ortak sorunu olduğu bilinmektedir. Bu da göstermektedir ki noktalama konusunda verilen eğitim amacına ulaşmamaktadır. İlkokuldan üniversiteye kadar her kademede öğretilen noktalama işaretlerinin kurallarına uygun kullanılamayışı bu durumun öğretimden başka sosyal boyutları da olabileceği düşüncesini doğurmaktadır. Bu noktada toplumsal bir sorun karşımıza çıkmakta ve devreye toplum dil bilimi girmektedir.

Toplum dil biliminin inceleme alanına giren bu çalışmanın yapısını anlayabilmek için önce toplum dil bilimini açıklamak gerekmektedir. İmer $(1990,15)$ "Toplum dil bilimi, dil bilimi ile toplum biliminin kesişme noktasında yer alan alanlar arası bir daldır. Ancak bu dal, doğrudan doğruya dilbilim ile toplum bilimin basit bir birleşimi değildir" diyerek toplum dil biliminin farklı disiplinlerin ilkeleri ile ortak çalıştığını ifade etmiştir. Vardar $(1980,144)$ toplum dil bilimini "Dil olgularlyla toplumsal olgular arasındaki ilişkileri, bunların birbirini etkilemesini, birbirinin değişkeni olarak ortaya çıkmasını, bir başka deyişle, bu iki tür olgu arasındaki eş değişirliği inceleyen karma dal. Toplum dil bilimi, hem konuşucunun hem de dinleyicinin toplumsal konumuyla bildirişim durumlarını, söylem çeşitlerini ele alır" şeklinde tanımlamış ve yine dilin toplumsal boyutuna dikkat çekmiştir.

Dil öğrenme ve dilin kurallarını uygulama becerisi kazandırılırken dilin toplumsal süreci göz ardı edilemez. Bir dili bilmek o dilin kurallarını, yapısını, işleyişini bilmek anlamına gelmez. Bir toplumda kullanılan ana dilin toplumun çeşitli katmanlarına göre farklılık gösterdiği bir gerçektir. Bir dili bilmek, dilin bu farklı katmanlara göre nasıl şekil aldığını bilmek ve öğrenilen ana dili duruma uygun kullanabilmekle mümkündür. Dil ile insanı, toplumu birbirinden ayırmak mümkün değildir. Toplumun dil kullanımı üzerindeki etkisini Huber $(2008,275)$ " $D i l$, yöresel farklıllklar gösterdiği gibi, mesleklere, cinsiyete, yaşa, katmana göre de ayrılıklar gösterir. Sözü edilen etmenler nedeniyle toplumsal gruplar oluşur, her toplumsal grup kendi dil kullanımını geliştirir" sözleriyle açıklamıştır. Huber burada farklı toplumsal katmanların farklı dil kullanım biçimleri olduğunu vurgulamıştır. Toplumsal katmanların oluşumunda etkili olan fak- 
törlerden biri de göçtür. Çünkü göç; eğitim, sosyo-ekonomik durum, kültürel yap1 gibi birçok toplum dil bilimi değişkenini hem sebep hem sonuç olarak bünyesinde barındırmaktadır. Bu olgular göç eden bireylerin toplumsal katmanlarının belirlenmesinde etkili olmaktadır. Bu sebeplerin birinden ya da birkaçından kaynaklı problemlerin dil kullanım biçimine yansıması, bu sorunu toplum dil bilimi çalışma alanı haline getirmektedir.

Dil ile toplumun bu kadar iç içe olması kuşkusuz dilin toplumdaki her türlü olumlu ya da olumsuz değişimden etkilenmesini de beraberinde getirmiştir. Türkiye'de 1950'li yıllardan itibaren hızla artan bir şekilde göç olgusu baş göstermiştir. Aker, et alii $(2002,98)$ göçün tanımını "Gö̧ insanın fiziksel çevresindeki istemli veya zorunlu, geçici veya kalıcı bir değişimdir. Sosyal, kültürel, ekonomik ve politik bazı değişikliklere yol açabileceği gibi aynı zamanda bu tür değişikliklerden de kaynak alabilir" şeklinde yapmışlardır.

Türkiye'nin şartları göz önüne alındığında, göç hareketlerinin çoğunlukla doğudan batıya iç göç şeklinde olmasından dolayı bu çalışmada sürekli iç göçler konu edilmiştir. Göç hareketinin sebepleri her toplumda aşağı yukarı aynıdır. Bu sebeplerden bazıları;

- Kırsal kesimde iş imkânlarının ve ekonomik imkânların sınırlı olması,

- Eğitim ve sağlık hizmetlerinin yetersizliği,

- Kentlerde sanayinin gelişmiş̧ olmasından dolayı iş olanaklarının fazlalığ1,

- Kentlerde eğitim ve sağlık hizmetlerinin yaygınlığı, olarak sıralanabilir.

Yukarıda sıralanan sebeplerden de görüldüğü gibi göçün itici güçlerinden biri de eğitim seviyesi düşük olan ve bulunduğu yerde iş imkânı olmayan insanların büyük kentlerde yüksek eğitim seviyesi gerektirmeyen işlerde çalışma isteğidir. Bu amaçla kentlere göç eden insanlar birçok olumsuz durumla karşılaşmakta ve bu durumlar kaçınılmaz olarak eğitim ortamına yansımaktadır.

$\mathrm{Bu}$ çalışmanın genel amacı, göç yaşamış öğrencilerin noktalama işaretlerini uygulama düzeylerini anne-baba eğitim durumu açısından incelemek, bulguları toplum dil bilimi açısından değerlendirmektir. $\mathrm{Bu}$ amaç doğrultusunda aşağıdaki sorulara cevap aranmıştır:

Göç yaşamış öğrencilerin;

a) Noktalama işaretlerini uygulama düzeyleri nedir?

b) Noktalama işaretlerini uygulama düzeyleri ile anne-baba eğitim durumları arasında anlamlı fark var midır?

\section{YÖNTEM}

\subsection{Araștırma Modeli}

Göç yaşamış çocukların noktalama işaretlerini uygulama düzeylerinin toplum dil bilim ilkeleri açısından incelenmesini amaçlayan bu çalışma betimsel niteliktedir. Yöntemi; olayları, olguları olduğu şekliyle tasvir etmeyi hedefleyen "alan araştırması" yöntemidir. Araştırmada "tarama modeli" ve "doküman inceleme tekniği" kullanılmıştır.

Yıldırım ve Şimşek $(2008,39)$ betimsel araştırmayı, "Kuram oluşturmayı temel alan bir anlayışla sosyal olguları bağlı bulundukları çevre içerisinde araştırmayı ve anlamayı ön plana alan bir yaklaşımdır" şeklinde açıklar.

Karasar $(2003,77)$ tarama modelini, "Var olan bir durumu var olduğu şekliyle betimlemeyi amaçlar. Araştırmaya konu olan olay, birey ya da nesne, kendi koşullar içinde ve olduğu gibi tanımlanmaya çalışılır. Onları, herhangi bir şekilde değiştirme, etkileme çabası gösterilmez. Önemli olan, bilinmek istenen şeyin gözlenip belirlenebilmesidir" şeklinde tarif eder.

Öğrencilerin noktalama işaretlerini uygulama düzeyi ile ilgili verilere ulaşmak için nitel 
araştırmalarda kullanılan doküman inceleme tekniğinden yararlanılmıştır. "Doküman incelemesi, araştırılması hedeflenen olgu veya olgular hakkında bilgi içeren yazılı materyallerin belli ölçütlere göre incelenmesini ve analizini kapsar" (Yıldırım, \& Şimşek, 2008).

\subsection{Evren ve Örneklem}

$\mathrm{Bu}$ araştırmanın evrenini Kocaeli’nin Körfez ilçesinde bulunan 8 ilköğretim okulunda okuyan 560 6. sınıf öğrencisi; örneklemini ise yine Körfez ilçesinde bulunan 4 ilköğretim okulundan toplam 214 6. sınıf öğrencisi oluşturmaktadır. Sekaran'a (1992, Akt. Altunışık, \& Bayraktaroğlu; Coşkun, \& Yıldırım, 2010) göre, örneklem büyük oranda evreni temsil etmektedir.

Evren ve örneklem belirlenirken "göç" unsuru temel ölçüt olarak alınmıştır. Öğrenciler seçilirken, göçü aileleri ile birlikte bizzat yaşayan öğrenciler olmalarına dikkat edilmiştir. Bu araştırmada sürekli iç göçler konu edildiği için öğrencilerin doğudaki köylerden ya da şehirlerden Kocaeli/Körfez'e gelmiş olmaları hususu gözetilmiştir. Bu şartlara uygun okulların seçimi için İlçe Milli Eğitim Müdürlüğü'nden yardım alınmıştır. Öğrencilerin seçimi için ise okulların idari personellerinden ve öğretmenlerin veli bilgi formlarından yararlanılmıştır.

Örneklem ise evreni oluşturan sekiz okul içerisinden "Kümelere göre örnekleme" yöntemiyle seçilmiştir. Kümelere göre örnekleme yönteminde, ortak özelliklere sahip grupların oluşturduğu evrenden örneklemi oluşturacak gruplar rastgele seçilir. Örnekleme ait eğitim bilgileri aşağıda verilmiştir.

Verilere göre annelerin çoğunluğu ilkokul mezunudur (\% 59,81). Bu durum annelerin eğitim seviyesinin oldukça düşük olduğunu göstermektedir. \% 15,89'luk bir kesimin ise hiç okuma yazması yoktur. En yüksek eğitim seviyesi lise mezunu annelerdedir ki onların da oranı sadece $\% 8,41^{\prime}$ dir.

Babaların eğitim durumu annelere göre daha iyi durumdadır. Babalarda okuma yazma olmayan kesim \% 1,87'dir. \% 50 ilkokul mezunu, \% 28,04 ortaokul mezunu, \% 15,89 lise mezunu ve sadece \% 4,21 üniversite mezunudur. Öğrencilerin sınıf rehber öğretmenlerinin veli bilgi formlarından alınan bilgilere göre üniversite mezunu babalar açık ögretim fakültesi veya ön lisans mezunudur.

\subsection{Veri Toplama Araçları}

Bu çalışmada öğrencilerin noktalama işaretlerini uygulama düzeylerini belirlemek için öğrencilere yazılı anlatım çalışması yaptırılmıştır. Öğrencilerin kendi ürünleri üzerinde ölçüm yapmanın daha nesnel verilere ulaşmada yardımcı olacağı düşünülmüştür. Öğretmenler gözetiminde öğrencilere iki ders saati verilmiş, belirlenen konu üzerinde serbest tarzda bir kompozisyon yazmaları istenmiştir.

Öğrencilere verilen yazılı bir yönerge ile yazılarında hangi noktalama işaretlerinin kullanım düzeyinin ölçüleceği ve kullanım düzeyi ölçülecek noktalama işaretlerini mutlaka kullanmaları gerektiği belirtilmiştir. Bu noktalama işaretlerinin işlevlerinden hangilerini öğrendikleri hatırlatılmış ve yazılarında bu işlevlerde kullanmalarının beklendiği söylenmiştir.

$\mathrm{Bu}$ yazılı anlatım çalışmalarında ölçülen noktalama işaretleri Talim ve Terbiye Kurulu Başkanlığı'nın düzenlediği Türkçe 6-8. Sınıflar Öğretim Programı'nda yer alan kurallardır. Özbay'ın (2011) “İlköğretim Türkçe Dersi (6-7-8. Sinıflar) Öğretim Programında Yazım ve Noktalama Kurallarının Sinıflara Göre Dağılımı" adlı çalışmasında da bu kurallar belirlenmiş ve listelenmiştir. Bu liste, öğrencilere uygulamaları gereken kuralları hatırlatmak amacıyla çoğaltılmış ve öğretmenler aracılığıyla dağıtılmıştır. 


\subsection{Noktalama İşaretlerinin Kullanım Düzeylerini Belirlemek İçin Kullanılan Ölçekler}

Karabuğa'nın (2011) yüksek lisans tezinde kullanılan “Noktalama Işsaretlerini Değerlendirme Ölçeğil" Karatay ile birlikte geliştirilmiş, ölçeğin geçerlik ve güvenirlik çalışmaları yapılmıştır. Karatay ile Karabuğa'nın izni ile bu ölçekler kullanılmıştır. Karabuğa'nın (2011) çalışmasında bu ölçeğin açılaması:

Noktalama işaretlerinin kullanım düzeylerinin tespitinde Türk Dil Kurumu tarafindan yayımlanan Yazım Kılavuzu (25. baskı, 2008) dikkate alınmıştır. Bu incelemelerde öğrencilerin noktalama yanlışları tespit edilmiştir. Bu tespitler yapılırken de öğrencilerin yazılı anlatım metinlerini puanlamak ve değerlendirmek için çeşitli ölçekler geliştirilmiştir. Yazım Kılavuzu'nda yer alan kurallar dikkate alınarak bir puanlama sistemi meydana getirilmiştir. Bu puanlama sisteminde öğrencilerin hangi kıstaslara göre zayıf düzeyde, orta düzeyde ya da iyi düzeyde oldukları tespit edilmeye çalışılmıştır. Öte yandan, eldeki tüm veriler IBM SPSS 20.00 programına yüklenerek istatistikî analizler yapılmıştır. Öğrencilerin yaptıkları noktalama yanlışları; yazılı anlatım metinlerinde kullanılması gereken yerlerde kullanılmayan noktalama işaretleri tespit edilerek noktalama işaretleri açısından öğrencilerin kullanım düzeyleri hakkında genel bir tablo ortaya konulmuştur. Ayrıca düzeyleri tespit edebilmek için aşağıdaki formülden de yararlanılmıştır:

Toplam kullanım sayısı $=$ Doğru sayısı $+($ Yanlış kullanım sayısı + Olması gerekenler $)$

İşaretin düzeyi = Doğru sayısı - (Yanlış sayısı + Olması gerekenler $)$

Düzeyin kategori sayısı

Kullanım düzeyleri zayıf, orta, iyi olarak ifade edilmiştir. Zayıf düzeydeki kullanım bir rakamıyla, orta düzeydeki kullanım iki rakamıyla, iyi düzeydeki kullanım üç rakamıyla ifade edilmiştir. 'Zayıf düzey 0-60 puan aralığı olarak; orta düzey 61-80 puan aralığı olarak; iyi düzey 81-100 puan aralığı olarak tespit edilmişti' şeklinde yapılmıştır. Öğrencilere bu konuda yönerge verildiği halde işareti veya kuralı hiç uygulamayan öğrenciler 'zayıf düzey kategorisinde değerlendirilmiştir' şeklinde yapılmıştır.

Karabuğa'nın ölçekleri "Türkçe Öğretmenliği Bölümü birinci sınıf ögrrencileri” için hazırlanmıştır. Bu ölçeklerden ilköğretim 6. sınıf öğrencilerinin Türkçe dersi içeriğinde yer almayan işaretler ve kurallar çıkarılmış, öğrencilerin birinci kademede öğrenerek geldiği varsayılan işaretler ve kurallar bırakılmıştır. Geriye bırakılan kuralların zayıf, orta, iyi düzey ölçütlerinin 6 . sınıf öğrencilerinin öğretim programı ile uyumlu olup olmadığı kontrol edilmiştir.

\section{5. Öğrencilerin Sosyo-Ekonomik Durumlarını Belirlemek İçin Kullanılan Veriler}

Öğrencilerin anne-baba eğitim seviyelerini belirlemek amacıyla veli bilgi formlarından yararlanılmıştır. Bu bilgiler öğrencilere anket olarak verildiğinde doğru cevaplar alınamamakta ve anketlerin geri dönüşünde problem yaşanmaktadır. Bu nedenle bilgilerin doğrudan veli bilgi formlarından alınması uygun görülmüştür. Alınan bu bilgiler grafik haline getirilmiştir.

\subsection{Verilerin İşlenmesi ve Çözümlenmesi}

Araştırmada toplanan veriler bilgisayara aktarılmış ve verilerin istatistikî analizinde IBM SPSS 20.00 (Statistic Package For Social Science) programından yararlanılmıştır. Araştırmanın problemlerine ilişkin verilerin analizinde kullanılan istatistikî teknikler sırasıyla aşağıda verilmiştir. Noktalama işaretlerine ait verilerin tanımlanmasında frekans (f), minimum (en alt düzey), maksimum (en üst düzey), genel toplam, aritmetik ortalama $(\bar{X})$, standart sapma (S) kullanılmıştır.

Normal dağılım göstermeyen kesme işareti, iki nokta, üç nokta ve tırnak işareti için "Tek 
Yönlü Manova" istatistik işlemi uygulanmıştır. Gruplar arasında anlamlı fark olup olmadığının tespiti için "Wilk's Lambda" değerine bakılmıştır. $(\mathrm{P}<0,05)$ ise normal dağılım göstermeyen her bir noktalama işareti için sosyo-ekonomik düzey değişkenlerine göre "Tek Yönlü Manova" analiz sonuçlarından $(\mathrm{P})$ anlamlılık düzeyine bakılmıştır. $(\mathrm{P}<0,05)$ ise anlamlı farkın anne, baba eğitim seviyesi değişkenlerinin hangi grupları arasında olduğunu tespit etmek için işaretlerin uygulama düzeyi ortalamalarının tanımlayıcı istatistiklerine bakılmıştır.

Normal dağılım göstermeyen kesme işareti, iki nokta, üç nokta ve tırnak işaretleri ile çocukların çalışma durumu arasında anlamlı fark olup olmadığını belirlemek için "MannWhitney U' testinden yararlanılmıştır.

\section{BULGULAR}

\subsection{Göç Yaşamış Öğrencilerin Noktalama Işaretlerini Uygulama Düzeyleri Nedir?}

Öğrencilerden alınan yazılı anlatım ürünleri önce noktalama işaretlerinin 6. sınıf düzeyinde kavratılan kullanım yerlerine göre incelenmiştir. Daha sonra, belirli ölçütlere göre hazırlanmış "Puanlama ve Değerlendirme" tablosu ile karşılaştırılmıştır. Bu tabloda zayıf, orta, iyi olmak üzere üç derece belirlenmiş ve bu derecelerin ölçütleri açıklanmıştır. Öğrencilerin kâğıtlarında noktalama işaretlerinin yanlış kullanıldığ 1 , doğru kullanıldığ 1 yerler ve toplam kullanım sayısı belirlenmiş̧tir. Belirlenen kullanımlar zayıf, orta, iyi düzey ölçütleri ile karşılaştırılmış ve sonuç tespit edilmiştir.

Aşağıdaki tabloda 6. Sınıf Türkçe Programı'nda yer alan noktalama işaretleri listelenmiştir. Listelenen işaretler öğrencilerin yazılı anlatım metinlerinde incelenmiş ve IBM SPSS 20.00 programı ile çözümlenmiştir. Her işarete ait; işaretin kaç öğrenci tarafından kullanıldığg (f), kullanım düzeyi alt (Min.) ve üst (Max.) sınırları, toplam kullanım sayısı (Toplam), kullanım düzeyi ortalaması $(\bar{X})$ gibi bilgiler verilmiştir.

Tablo 3.1. Noktalama İşaretlerinin Kullanım Düzeyleri.

\begin{tabular}{|l|c|c|c|c|c|c|}
\hline & f & $\begin{array}{c}\text { Min. -En } \\
\text { alt (düzey) }\end{array}$ & $\begin{array}{c}\text { Maks. -En } \\
\text { üst (düzey) }\end{array}$ & Toplam & $\begin{array}{c}\bar{X} \\
(\mathbf{1 . 0 0 - 3 . 0 0 )}\end{array}$ & S \\
\hline 1. Nokta & 214 & 1 & 3 & 504 & 2,36 & 0,848 \\
\hline 2. Virgül & 214 & 1 & 3 & 356 & 1,66 & 0,833 \\
\hline 3. Kısa Çizgi & 214 & 1 & 3 & 432 & 2,02 & 0,978 \\
\hline 4. Kesme İşareti & 214 & 1 & 3 & 282 & 1,32 & 0,707 \\
\hline 5. İki Nokta & 214 & 1 & 3 & 282 & 1,32 & 0,680 \\
\hline 6. Soru işareti & 214 & 1 & 3 & 250 & 1,17 & 0,556 \\
\hline 7. Noktalı virgül & 214 & 1 & 3 & 234 & 1,09 & 0,423 \\
\hline 8. Üç nokta & 214 & 1 & 3 & 242 & 1,13 & 0,496 \\
\hline 9. Tırnak işareti & 214 & 1 & 3 & 264 & 1,23 & 0,637 \\
\hline 10. Ünlem işareti & 214 & 1 & 3 & 228 & 1,07 & 0,343 \\
\hline 11. Yay ayraç & 214 & 1 & 3 & 218 & 1,02 & 0,193 \\
\hline 12. Uzun çizgi & 214 & 1 & 1 & 214 & 1,00 & 0 \\
\hline 13. Eğik çizgi & 214 & 1 & 1 & 214 & 1,00 & 0 \\
\hline
\end{tabular}

Not: 1,00-1,49: zayıf düzey / 1,50-2,49: orta düzey / 2,50-3,00: iyi düzey. 
Tablo 3.1'e göre;

Nokta: Öğrenciler nokta işaretini orta düzeyde $(\bar{X}=2,36)$ kullanmıştır. Bu işaret bütün öğrenciler tarafindan kullanılmıştır.

Virgül: Virgülü kullanan göç yaşamış öğrenciler bu işareti orta düzeyde $(\bar{X}=1,66)$ kullanmaktadır.

Kısa çizgi: Kısa çizgiyi kullanan göç yaşamış öğrencilerin bu işareti uygulama düzeyi ortalaması $(\bar{X}=2,02)$ ile orta düzeydedir.

Kesme işareti: Kesme işaretinin kullanımı $(\bar{X}=1,32)$ ile zayıf düzeydedir.

İki nokta: İki nokta işaretinin kullanımı $(\bar{X}=1,32)$ ile zayıf düzeydedir.

Soru işareti: Soru işaretinin kullanımı $(\bar{X}=1,17)$ ile zayıf düzeydedir.

Noktalı virgül: Noktalı virgül işaretinin kullanım düzeyi zayıf $(\bar{X}=1,09)$ 'tır.

Üç nokta: Üç nokta işaretinin kullanım düzeyi ortalaması $(\bar{X}=1,13)$ ' lük oranla zayıftır.

Tırnak işareti: Tırnak işaretinin kullanım düzeyi zayıf $(\bar{X}=1,23)$ 'tır.

Ünlem işareti: Ünlem işaretinin kullanım düzeyi ise $(\bar{X}=1,07)^{\prime}$ dir ve zayıftır.

Yay ayraç: Yay ayracın kullanım düzeyi ortalaması ise zayıf $(\bar{X}=1,02)^{\prime}$ tır.

Uzun çizgi: Uzun çizginin kullanım düzeyi zayıf $(\bar{X}=1)$ 'tır.

Eğik çizgi öğrenciler tarafından hiç kullanılmadığı için kullanım düzeyi ortalaması zayıf olarak alınmıştır.

\subsection{Göç Yaşamış Öğrencilerin Aile Eğitim Durumları İle Noktalama İşaretlerini Uygu- lama Düzeyleri Arasında Anlamlı Fark Var Mıdır?}

Öğrencilerin noktalama işaretlerini uygulama düzeyi ortalamaları ile anne eğitim durumu arasında anlamlı fark olup olmadığını tespit etmek için normal dağılım gösteren nokta, virgül, kısa çizgi, soru işareti, noktalı virgül, ünlem, yay ayraç, uzun çizgi, eğik çizgi işaretleri için "Tek Yönlü Anova"; normal dağılım göstermeyen kesme işareti, iki nokta, üç nokta ve tırnak işareti için "Tek Yönlü Manova" istatistik işlemleri uygulanmıştır.

Tablo 3.2. Göç yaşamış öğrencilerin noktanın yazımı kuralını uygulama düzey ortalamalarının anne eğitim durumlarına göre "Tek Yönlü Anova" analizi sonuçları.

\begin{tabular}{|l|c|c|c|c|c|c|}
\hline $\begin{array}{c}\text { Varyansın } \\
\text { Kaynağı }\end{array}$ & $\begin{array}{c}\text { Kareler } \\
\text { Toplamı }\end{array}$ & sd & $\begin{array}{c}\text { Kareler } \\
\text { Ortalaması }\end{array}$ & $\mathbf{F}$ & $\mathbf{p}$ & Anlamlı Farklar \\
\hline Gruplararası & 3,917 & 3 & 1,306 & 1,839 & 0,141 & \\
\hline Gruplariçi & 149,092 & 210 & 0,710 & & & \\
\hline Toplam & 153,009 & 213 & & & \\
\hline \multicolumn{7}{c|}{$\left[\mathrm{F}_{(3-210)}=1,839-\mathrm{p}>0,05\right]$. Hipotez Kabul Edilmemiştir. } \\
\hline
\end{tabular}

(1: Okuma-yazma yok, 2: İlkokul mezunu, 3: Ortaokul mezunu, 4: Lise mezunu)

Tablo 3.2' ye göre göç yaşamış öğrencilerin nokta işaretini uygulama düzeyleri ortalamaları ile annelerin eğitim durumlarına göre anlamlı fark tespit edilmemiştir $\left(\mathrm{F}_{(3-210)}=1,839-\mathrm{p}>0,05\right)$. Başka bir deyişle öğrencilerin nokta işaretini uygulama düzeyleri annelerin eğitim durumuna göre değişmemektedir. Yapılan analizlere göre; annesi okuma-yazma bilmeyen öğrencilerin ortalaması $(\bar{X}=2,29)$, annesi ilkokul mezunu olanların ortalaması $(\bar{X}=2,32)$, ortaokul mezunu olanlarınki $(\bar{X}=2,41)$, lise mezunu olanlarınki $(\bar{X}=2,78)^{\prime}$ dir. 
Tablo 3.3. Göç yaşamış öğrencilerin virgülün yazımı kuralını uygulama düzey ortalamalarının anne eğitim durumlarına göre "Tek Yönlü Anova" analizi sonuçları.

\begin{tabular}{|l|c|c|c|c|c|c|}
\hline $\begin{array}{c}\text { Varyansın } \\
\text { Kaynağı }\end{array}$ & $\begin{array}{c}\text { Kareler } \\
\text { Toplamı }\end{array}$ & sd & $\begin{array}{c}\text { Kareler } \\
\text { Ortalaması }\end{array}$ & F & P & Anlamlı Farklar \\
\hline Gruplararası & 14,469 & 3 & 4,823 & 7,598 & 0,000 & $1-4,2-4,3-4$ \\
\hline Gruplariçi & 133,307 & 210 & 0,635 & & & \\
\hline Toplam & 147,776 & 213 & & & & \\
\hline \multicolumn{7}{|c|}{$\left[\mathrm{F}_{(3-210)}=7,598-\mathrm{p}<0,05\right]$. Hipotez Kabul Edilmiştir. } \\
\hline
\end{tabular}

(1: Okuma-yazma yok, 2: İlkokul mezunu, 3: Ortaokul mezunu, 4: Lise mezunu)

Tablo 3.3'e göre göç yaşamış öğrencilerin virgül işaretini uygulama düzeyleri ortalamaları arasında annelerin eğitim durumlarına göre anlamlı fark tespit edilmiştir $\left(F_{(3-210)}=7,598-p<0,05\right)$. Birimler arası farkların hangi gruplar arasında olduğunu tespit etmek amaciyla yapılan "Scheffe" testinin sonuçlarına göre, annesi lise mezunu olanların virgülü kullanım düzeyi ortalaması $(\bar{X}=2,50)$ ile; annesi okuma-yazma bilmeyen öğrencilerin ortalaması $(\bar{X}=1,55)$, annesi ilkokul mezunu olanların ortalaması $(\bar{X}=1,62)$ ve annesi ortaokul mezunu olanların ortalaması $(\bar{X}=1,71)$ arasında anlamlı fark tespit edilmiştir.

Tablo 3.4. Göç yaşamış öğrencilerin kısa çizginin yazımı kuralını uygulama düzey ortalamalarının anne eğitim durumlarına göre Tek-Yönlü Anova analizi sonuçları.

\begin{tabular}{|l|c|c|c|c|c|c|}
\hline $\begin{array}{c}\text { Varyansın } \\
\text { Kaynağı }\end{array}$ & $\begin{array}{c}\text { Kareler } \\
\text { Toplamı }\end{array}$ & sd & $\begin{array}{c}\text { Kareler } \\
\text { Ortalaması }\end{array}$ & F & p & Anlamlı Farklar \\
\hline Gruplararası & 7,869 & 3 & 2,623 & 2,809 & 0,041 & $1-4,2-4$ \\
\hline Gruplariçi & 196,057 & 210 & 0,934 & & & \\
\hline Toplam & 203,925 & 213 & & & \\
\hline \multicolumn{7}{|c|}{$\left[\mathrm{F}_{(3-210)}=2,809-\mathrm{p}<0,05\right]$. Hipotez Kabul Edilmiştir. } \\
\hline
\end{tabular}

(1: Okuma-yazma yok, 2: İlkokul mezunu, 3: Ortaokul mezunu, 4: Lise mezunu)

Tablo 3.4'e göre göç yaşamış öğrencilerin kısa çizgiyi uygulama düzeyleri ortalamaları arasında annelerin eğitim durumlarına göre anlamlı fark tespit edilmiştir $\left(\mathrm{F}_{(3-210)}=2,809-\mathrm{p}<0,05\right)$. Birimler arası farkların hangi gruplar arasında olduğunu tespit etmek amaciyla yapılan "Dunnett's $C$ " testinin sonuçlarına göre; annesi lise mezunu olanların kısa çizgiyi uygulama düzeyi ortalaması $(\bar{X}=2,61)$ ile; annesi okuma-yazma bilmeyen öğrencilerin ortalaması $(\bar{X}=1,93)$ ve annesi ilkokul mezunu olanların ortalaması $(\bar{X}=1,94)$ arasında anlamlı fark tespit edilmiştir.

Tablo 3.5. Göç yaşamış öğrencilerin soru işaretini uygulama düzey ortalamalarının anne eğitim durumlarına göre "Tek Yönlü Anova" analizi sonuçları.

\begin{tabular}{|l|c|c|c|c|c|c|}
\hline $\begin{array}{c}\text { Varyansın } \\
\text { Kaynağı }\end{array}$ & $\begin{array}{c}\text { Kareler } \\
\text { Toplamı }\end{array}$ & sd & $\begin{array}{c}\text { Kareler } \\
\text { Ortalaması }\end{array}$ & F & p & Anlamlı Farklar \\
\hline Gruplararası & 13,657 & 3 & 4,552 & 18,284 & 0,000 & $1-4,2-4,3-4$ \\
\hline Gruplariçi & 52,287 & 210 & 0,249 & & & \\
\hline Toplam & 65,944 & 213 & & & & \\
\hline & {$\left[\mathrm{F}_{(3-210)}=18,284-\mathrm{p}<0,05\right]$. Hipotez Kabul Edilmiştir. } \\
\hline
\end{tabular}


(1: Okuma-yazma yok, 2: İlkokul mezunu, 3: Ortaokul mezunu, 4: Lise mezunu)

Tablo 3.5'e göre göç yaşamış öğrencilerin soru işaretini uygulama düzeyleri ortalamaları arasında annelerin eğitim durumlarına göre anlamlı fark tespit edilmiştir $\left(\mathrm{F}_{(3-210)}=18,284-\mathrm{p}<0,05\right)$. Birimler arası farkların hangi gruplar arasında olduğunu tespit etmek amaciyla yapılan "Dunnett's $C$ " testinin sonuçlarına göre; annesi lise mezunu olanların kısa çizgiyi uygulama düzeyi ortalaması $(\bar{X}=2,00)$ ile; annesi okuma-yazma bilmeyen ögrrencilerin ortalaması $(\bar{X}=1,06)$, annesi ilkokul mezunu olanların ortalamas $(\bar{X}=1,09)$ ve annesi ortaokul mezunu olanların ortalaması $(\bar{X}=1,12)$, arasında anlamlı fark tespit edilmiştir.

Tablo 3.6. Göç yaşamış öğrencilerin noktalı virgülü uygulama düzey ortalamalarının anne eğitim durumlarına göre "Tek Yönlü Anova" analizi sonuçları.

\begin{tabular}{|l|c|c|c|c|c|c|}
\hline $\begin{array}{c}\text { Varyansın } \\
\text { Kaynağı }\end{array}$ & $\begin{array}{c}\text { Kareler } \\
\text { Toplamı }\end{array}$ & sd & $\begin{array}{c}\text { Kareler } \\
\text { Ortalaması }\end{array}$ & F & p & Anlamlı Farklar \\
\hline Gruplararası & 6,726 & 3 & 2,242 & 14,993 & 0,000 & $1-4$ \\
\hline Gruplariçi & 31,404 & 210 & 0,150 & & & \\
\hline Toplam & 38,131 & 213 & & & & \\
\hline \multicolumn{7}{|c|}{$\left[\mathrm{F}_{(3-210)}=14,993-\mathrm{p}<0,05\right]$. Hipotez Kabul Edilmiştir. } \\
\hline
\end{tabular}

(2: İlkokul mezunu, 3: Ortaokul mezunu, 4: Lise mezunu)

Tablo 3.6'ya göre göç yaşamış öğrencilerin noktalı virgülü uygulama düzeyleri ortalamaları arasında annelerin eğitim durumlarına göre anlamlı fark tespit edilmiştir $\left(\mathrm{F}_{(3-210)}=14,99\right.$ $\mathrm{p}<0,05)$. Birimler arası farkların hangi gruplar arasında olduğunu tespit etmek amacıyla yapılan "Dunnett's $C$ " testinin sonuçlarına göre, annesi lise mezunu olanların kısa çizgiyi uygulama düzeyi ortalaması $(\bar{X}=1,67)$ ile; annesi okuma-yazma bilmeyen öğrencilerin ortalaması $(X=1,00)$ arasında anlamlı fark tespit edilmiştir.

Tablo 3.7. Göç yaşamış öğrencilerin ünlem işaretini uygulama düzey ortalamalarının anne eğitim durumlarına göre "Tek Yönlü Anova" analizi sonuçları.

\begin{tabular}{|l|c|c|c|c|c|c|}
\hline $\begin{array}{c}\text { Varyansın } \\
\text { Kaynağı }\end{array}$ & $\begin{array}{c}\text { Kareler } \\
\text { Toplamı }\end{array}$ & sd & $\begin{array}{c}\text { Kareler } \\
\text { Ortalaması }\end{array}$ & F & p & Anlamlı Farklar \\
\hline Gruplararası & 2,174 & 3 & 0,725 & 6,643 & 0,000 & $1-4,2-4$ \\
\hline Gruplariçi & 22,910 & 210 & 0,109 & & & \\
\hline Toplam & 25,084 & 213 & & & & \\
\hline \multicolumn{7}{|c|}{$\left[\mathrm{F}_{(3-210)}=6,643-\mathrm{p}<0,05\right]$. Hipotez Kabul Edilmiştir. } \\
\hline
\end{tabular}

(1: Okuma-yazma yok, 2: İlkokul mezunu, 3: Ortaokul mezunu, 4: Lise mezunu)

Tablo 3.7'ye göre göç yaşamış öğrencilerin ünlem işaretini uygulama düzeyleri ortalamaları arasında annelerin eğitim durumlarına göre anlamlı fark tespit edilmiştir $\left(\mathrm{F}_{(3-210)}=6,643\right.$ $\mathrm{p}<0,05)$. Birimler arası farkların hangi gruplar arasında olduğunu tespit etmek amacıyla yapılan "Dunnett's $C$ " testinin sonuçlarına göre, annesi lise mezunu olanların ünlem işaretini uygulama düzeyi ortalaması $(X=1,33)$ ile; annesi okuma-yazma bilmeyen öğrencilerin ortalaması $(\bar{X}$ $=1,00)$ ve annesi ilkokul mezunu olan öğrencilerin ortalaması $(\bar{X}=1,02)$ arasında anlamlı fark tespit edilmiştir. 
Tablo 3.8. Göç yaşamış öğrencilerin yay ayracı uygulama düzey ortalamalarının anne eğitim durumlarına göre "Tek Yönlü Anova" analizi sonuçları.

\begin{tabular}{|l|c|c|c|c|c|c|}
\hline $\begin{array}{l}\text { Varyansın } \\
\text { Kaynağı }\end{array}$ & $\begin{array}{c}\text { Kareler } \\
\text { Toplamı }\end{array}$ & sd & $\begin{array}{c}\text { Kareler } \\
\text { Ortalaması }\end{array}$ & F & p & Anlamlı Farklar \\
\hline Gruplararası &, 179 & 3 & 0,060 & 1,615 & 0,187 & \\
\hline Gruplariçi & 7,747 & 210 & 0,037 & & & \\
\hline Toplam & 7,925 & 213 & & & & \\
\hline \multicolumn{7}{|c|}{$\left[\mathrm{F}_{(3-210)}=1,615-\mathrm{p}>0,05\right]$. Hipotez Kabul Edilmemiştir. } \\
\hline
\end{tabular}

(1: Okuma-yazma yok, 2: İlkokul mezunu, 3: Ortaokul mezunu, 4: Lise mezunu)

Tablo 3.8'e göre göç yaşamış öğrencilerin yay ayracı uygulama düzeyleri ortalamaları arasında annelerin eğitim durumlarına göre anlamlı fark tespit edilmemiştir. $\left(F_{(3-210)}=1,615-p>0,05\right)$. Diğer bir deyişle öğrencilerin yay ayracı uygulama düzeyleri annelerin eğitim düzeyine göre farklı1ık göstermemektedir. Annesi okuma-yazma bilmeyen göç yaşamış öğrencilerin yay ayracı uygulama düzeyi ortalaması $(\bar{X}=1,00)$, annesi ilkokul mezunu olanların ortalaması $(\bar{X}=1,00)$, annesi ortaokul mezunu olan öğrencilerin ortalaması $(\bar{X}=1,02)$, annesi lise mezunu olanların ortalaması ise $(\bar{X}=1,11)^{\prime}$ dir.

Tablo 3.9. Göç yaşamış öğrencilerin uzun çizgiyi uygulama düzey ortalamalarının anne eğitim durumlarına göre "Tek Yönlü Anova" analizi sonuçları.

\begin{tabular}{|l|c|c|c|c|c|c|}
\hline \multicolumn{1}{|c|}{$\begin{array}{c}\text { Varyansın } \\
\text { Kaynağı }\end{array}$} & $\begin{array}{c}\text { Kareler } \\
\text { Toplamı }\end{array}$ & sd & $\begin{array}{c}\text { Kareler } \\
\text { Ortalaması }\end{array}$ & F & p & Anlamlı Farklar \\
\hline Gruplararası & 0,000 & 3 & 0,000 & & & \\
\hline Gruplariçi & 0,000 & 210 & 0,000 & & & \\
\hline Toplam & 0,000 & 213 & & & & \\
\hline
\end{tabular}

"Anova" testiyle, uzun çizgiyi uygulama düzeylerinin ortalaması ile anne eğitim durumları arasında bir analiz yapılamamıştır.

Tablo 3.10. Göç yaşamış öğrencilerin eğik çizgiyi uygulama düzey ortalamalarının anne eğitim durumlarına göre "Tek Yönlü Anova" analizi sonuçları.

\begin{tabular}{|l|c|c|c|c|c|c|}
\hline \multicolumn{1}{|c|}{$\begin{array}{c}\text { Varyansın } \\
\text { Kaynağı }\end{array}$} & $\begin{array}{c}\text { Kareler } \\
\text { Toplamı }\end{array}$ & sd & $\begin{array}{c}\text { Kareler } \\
\text { Ortalaması }\end{array}$ & F & P & Anlamlı Farklar \\
\hline Gruplararası & 0,000 & 3 & 0,000 & & & \\
\hline Gruplariçi & 0,000 & 210 & 0,000 & & & \\
\hline Toplam & 0,000 & 213 & & & & \\
\hline
\end{tabular}

Eğik çizgi öğrenciler tarafından hiç kullanılmadığı için "Anova" testiyle eğik çizgiyi uygulama düzeyleri ortalaması ile anne eğitim durumları arasında bir analiz yapılamamıştır. 
Tablo 3.11. Kesme işareti, iki nokta, üç nokta ve tırnak işaretini kullanım düzey ortalamalarının anne eğitim durumlarına çoklu karşılaştırma test sonuçları.

\begin{tabular}{|c|c|c|c|c|c|}
\hline \multicolumn{2}{|c|}{ Etki } & Değer & F & p & Kismi Eta \\
\cline { 5 - 6 } & & & & Kare \\
\hline Kesişme & Pillai's Trace & 0,893 & 431,401 & 0,000 & 0,893 \\
\hline & Wilks' Lambda & 0,107 & 431,401 & 0,000 & 0,893 \\
\hline & Hotelling's Trace & 8,336 & 431,401 & 0,000 & 0,893 \\
\hline \multirow{2}{*}{ Anne Eğitim Durumu } & Roy's Largest Root & 8,336 & 431,401 & 0,000 & 0,893 \\
\hline & Pillai's Trace & 0,310 & 6,020 & 0,000 & 0,103 \\
\hline & Wilks' Lambda & 0,704 & 6,486 & 0,000 & 0,111 \\
\hline & Hotelling's Trace & 0,402 & 6,888 & 0,000 & 0,118 \\
\hline & Roy's Largest Root & 0,349 & 18,236 & 0,000 & 0,259 \\
\hline
\end{tabular}

Tablo 3.11, çoklu karşılaştırma test sonuçları göç yaşamış öğrencilerin anne eğitim durumuna göre kesme işaretini, iki nokta, üç nokta ve tırnak işaretini kullanım düzeyi ortalamaları arasında anlamlı farklılık olduğunu ortaya koymaktadır $(\Lambda=0,704, \mathrm{p}<0,05)$. Farklılıkların hangi gruplar arasında olduğunu incelemek amacıyla "Tek-Yönlü Manova" analiz sonuçları incelenmiştir.

Tablo 3.12. Kesme işareti, iki nokta, üç nokta ve tırnak işaretini kullanım düzey ortalamalarının anne eğitim durumlarına göre "Tek Yönlü Manova" analizi sonuçları.

\begin{tabular}{|l|l|c|c|c|c|c|}
\hline \multirow{2}{*}{ Kaynak } & \multirow{2}{*}{ Bağımlı Değişken } & \multirow{2}{*}{ Sd } & Kareler & \multirow{2}{*}{ F } & \multirow{2}{*}{$\mathbf{p}$} & Kısmi Eta \\
\cline { 6 - 7 } & & & Ortalaması & & & Kare \\
\hline Düzeltilmiş & Kesme işareti & 3 & 4,779 & 10,902 & 0,000 & 0,135 \\
\hline Model & İki nokta & 3 & 3,574 & 8,560 & 0,000 & 0,109 \\
\hline & Üç nokta & 3 & 3,117 & 15,226 & 0,000 & 0,179 \\
\hline & Tırnak işareti & 3 & 3,752 & 10,497 & 0,000 & 0,130 \\
\hline Kesişme & Kesme işareti & 1 & 299,322 & 682,823 & 0,000 & 0,765 \\
\hline & İki nokta & 1 & 273,784 & 655,794 & 0,000 & 0,757 \\
\hline & Üç nokta & 1 & 213,125 & 1041,180 & 0,000 & 0,832 \\
\hline \multirow{2}{*}{ Anne Eğitim } & Tırnak işareti & 1 & 238,346 & 666,816 & 0,000 & 0,760 \\
\hline Durumu & Kesme işareti & 3 & 4,779 & 10,902 & 0,000 & 0,135 \\
\hline & İki nokta & 3 & 3,574 & 8,560 & 0,000 & 0,109 \\
\hline & Üç nokta & 3 & 3,117 & 15,226 & 0,000 & 0,179 \\
\hline Hata & Tırnak işareti & 3 & 3,752 & 10,497 & 0,000 & 0,130 \\
\hline & Kesme işareti & 210 & 0,438 & & & \\
\hline & İki nokta & 210 & 0,417 & & & \\
\hline & Üç nokta & 210 & 0,205 & & & \\
\hline
\end{tabular}




\begin{tabular}{|l|l|c|c|l|l|l|}
\hline & Tırnak işareti & 210 & 0,357 & & & \\
\hline Toplam & Kesme işareti & 214 & & & & \\
\hline & İki nokta & 214 & & & & \\
\hline & Üç nokta & 214 & & & & \\
\hline Düzeltilmiş & Tirnak işareti & 214 & & & & \\
\hline Toplam & İki nokta & 213 & & & & \\
\hline & Üç nokta & 213 & & & & \\
\hline & Tirnak işareti & 213 & & & & \\
\hline
\end{tabular}

Tablo 3.12'ye bakıldığında anne eğitim durumuna göre kesme işaretinin kullanım düzey ortalamaları arasında $\left(\mathrm{F}_{(3-210)}=10,902-\mathrm{p}<0,05\right)$, iki noktanın kullanım düzey ortalamaları arasında $\left(\mathrm{F}_{(3-}\right.$ $\left.{ }_{210}=8,560-\mathrm{p}<0,05\right)$, üç noktanın kullanım düzeyi ortalamaları arasında $\left(\mathrm{F}_{(3-210)}=15,226\right.$ $\mathrm{p}<0,05)$,tırnak işaretinin kullanım düzeyi ortalamaları arasında $\left(\mathrm{F}_{(3-210)}=10,497-\mathrm{p}<0,05\right)$ anlamlı farklılık tespit edilmiştir. Bu durum öğrencilerin anne eğitim durumları ile noktalama işaretlerini uygulama düzeyi arasında bir ilişki olduğunu göstermektedir.

Tablo 3.13. Kesme işareti, iki nokta, üç nokta ve tırnak işaretini kullanım düzey ortalamalarının anne eğitim durumlarına göre tanımlayıcı istatistikler.

\begin{tabular}{|c|c|c|c|c|}
\hline & $\begin{array}{c}\text { Anne Eğitim } \\
\text { Durumu }\end{array}$ & Ortalama & $\begin{array}{c}\text { Standart } \\
\text { Sapma }\end{array}$ & $\begin{array}{c}\text { Örneklem } \\
\text { Büyüklüğü }\end{array}$ \\
\hline \multirow{5}{*}{ Kesme işareti } & Okuma-Yazma yok & 1,38 & 0,739 & 34 \\
\hline & İlkokul & 1,17 & 0,563 & 128 \\
\hline & Ortaokul & 1,38 & 0,697 & 34 \\
\hline & Lise & 2,11 & 1,023 & 18 \\
\hline & Toplam & 1,32 & 0,707 & 214 \\
\hline \multirow{5}{*}{ İki nokta } & Okuma-Yazma yok & 1,24 & 0,606 & 34 \\
\hline & İlkokul & 1,26 & 0,631 & 128 \\
\hline & Ortaokul & 1,24 & 0,606 & 34 \\
\hline & Lise & 2,06 & 0,873 & 18 \\
\hline & Toplam & 1,32 & 0,680 & 214 \\
\hline \multirow{5}{*}{ Üç nokta } & Okuma-Yazma yok & 1,06 & 0,343 & 34 \\
\hline & İlkokul & 1,03 & 0,249 & 128 \\
\hline & Ortaokul & 1,24 & 0,654 & 34 \\
\hline & Lise & 1,78 & 1,003 & 18 \\
\hline & Toplam & 1,13 & 0,496 & 214 \\
\hline \multirow{3}{*}{ Tirnak işareti } & Okuma-Yazma yok & 1,00 & 0,000 & 34 \\
\hline & İlkokul & 1,19 & 0,585 & 128 \\
\hline & Ortaokul & 1,26 & 0,666 & 34 \\
\hline
\end{tabular}




\begin{tabular}{|c|c|c|c|c|}
\hline & Lise & 1,94 & 0,998 & 18 \\
\cline { 2 - 5 } & Toplam & 1,23 & 0,637 & 214 \\
\hline
\end{tabular}

Tablo 3.13'de görüldügü üzere annesi lise mezunu olanların kesme işaretini uygulama düzeyi ortalaması $(\bar{X}=2,11)$ ile; annesi okuma-yazma bilmeyen öğrencilerin ortalaması $(\bar{X}=1,38)$, annesi ilkokul mezunu olan öğrencilerin ortalaması $(\bar{X}=1,17)$ ve annesi ortaokul mezunu olan öğrencilerin ortalaması $(\bar{X}=1,38)$ arasında anlamlı fark tespit edilmiştir.

Annesi lise mezunu olan öğrencilerin iki nokta işaretini uygulama düzeyi ortalaması $(\bar{X}$ $=2,06)$ ile; annesi okuma-yazma bilmeyen öğrencilerin ortalaması $(\bar{X}=1,24)$, annesi ilkokul mezunu olan öğrencilerin ortalaması $(\bar{X}=1,26)$ ve annesi ortaokul mezunu olan öğrencilerin ortalaması $(\bar{X}=1,24)$ arasında anlamlı fark tespit edilmiştir.

Üç nokta işaretinin ortalamaları ise şöyledir: Annesi lise mezunu olanların üç nokta işaretini uygulama düzeyi ortalaması $(\bar{X}=1,78)$ ile; annesi okuma-yazma bilmeyen öğrencilerin ortalaması $(\bar{X}=1,06)$, annesi ilkokul mezunu olan öğrencilerin ortalaması $(\bar{X}=1,03)$ ve annesi ortaokul mezunu olan öğrencilerin ortalaması $(\bar{X}=1,24)$ arasında anlamlı fark tespit edilmiştir.

Son olarak annesi lise mezunu olanların tırnak işaretini uygulama düzeyi ortalaması $(\bar{X}=1,94)$ ile; annesi okuma-yazma bilmeyen öğrencilerin ortalaması $(\bar{X}=1,00)$, annesi ilkokul mezunu olan öğrencilerin ortalaması $(\bar{X}=1,19)$ ve annesi ortaokul mezunu olan öğrencilerin ortalaması $(\bar{X}=1,26)$ arasında anlamlı fark tespit edilmiştir.

Yukarıdaki analiz sonuçlarına göre annelerin eğitim durumu arttıkça çocukların noktalama işaretlerini uygulama düzeyi ortalamaları da artmaktadır. Bu durum sosyo-kültürel yapının eğitim ortamına yansımasının bir örneğidir.

Öğrencilerin noktalama işaretlerini uygulama düzeyi ortalamaları ile babalarının eğitim durumu arasında anlamlı fark olup olmadığını tespit etmek için normal dağılım gösteren nokta, virgül, kısa çizgi, soru işareti, noktalı virgül, ünlem, yay ayraç, uzun çizgi, eğik çizgi işaretleri için "Tek Yönlü Anova"; normal dağılım göstermeyen kesme işareti, iki nokta, üç nokta ve tırnak işareti için "Tek Yönlü Manova" istatistik işlemleri uygulanmıştır.

Tablo 3.14. Göç yaşamış öğrencilerin nokta işaretini uygulama düzey ortalamalarının baba eğitim durumlarına göre "Tek Yönlü Anova" analizi sonuçları.

\begin{tabular}{|l|c|c|c|c|c|c|}
\hline $\begin{array}{c}\text { Varyansın } \\
\text { Kaynağı }\end{array}$ & $\begin{array}{c}\text { Kareler } \\
\text { Toplamı }\end{array}$ & sd & $\begin{array}{c}\text { Kareler } \\
\text { Ortalaması }\end{array}$ & F & P & Anlamlı Farklar \\
\hline Gruplararası & 3,247 & 4 & 0,812 & 1,133 & 0,342 & \\
\hline Gruplariçi & 149,762 & 209 & 0,717 & & & \\
\hline Toplam & 153,009 & 213 & & & \\
\hline \multicolumn{7}{|c|}{$\left[\mathrm{F}_{(4-209)}=1,133-\mathrm{p}>0,05\right]$. Hipotez Kabul Edilmemiştir. } \\
\hline
\end{tabular}

(1: Okuma-yazma yok, 2: İlkokul, 3: Ortaokul, 4: Lise, 5: Üniversite)

Tablo 3.14'te görüldüğü gibi göç yaşamış öğrencilerin nokta işaretini uygulama düzeyleri ortalamaları ile babaların eğitim durumları arasında anlamlı fark tespit edilmemiştir. $\left(\mathrm{F}_{(4-209)}=1,133\right.$ $\mathrm{p}>0,05)$. Babası okuma-yazma bilmeyen öğrencilerin ortalaması $(\bar{X}=1,75)$, babası ilkokul mezunu olanların ortalaması $(\bar{X}=2,34)$, babası ortaokul mezunu olanların ortalaması $(\bar{X}=2,33)$, babası lise mezunu olanların ortalaması $(\bar{X}=2,41)$ ve babası üniversite mezunu olanların ortalamasi $(\bar{X}=2,78)$ 'dir. 
Tablo 3.15. Göç yaşamış öğrencilerin virgülü uygulama düzeyleri ile baba eğitim eğitim durumlarına göre "Tek Yönlü Anova" analizi sonuçları.

\begin{tabular}{|c|c|c|c|c|c|c|}
\hline $\begin{array}{c}\text { Varyansın } \\
\text { Kaynağı }\end{array}$ & $\begin{array}{l}\text { Kareler } \\
\text { Toplamı }\end{array}$ & sd & $\begin{array}{c}\text { Kareler } \\
\text { Ortalaması }\end{array}$ & F & $\mathbf{P}$ & Anlamlı Farklar \\
\hline Gruplararası & 16,626 & 4 & 4,157 & 6,624 & 0,000 & $\begin{array}{cccc}1-2 & 1-3 & 1-4 & 1-5 \\
2-5 & 3-5 & 4-5\end{array}$ \\
\hline Gruplariçi & 131,149 & 209 & 0,628 & & & \\
\hline Toplam & 147,776 & 213 & & & & \\
\hline
\end{tabular}

(1: Okuma-yazma yok, 2: İlkokul, 3: Ortaokul, 4: Lise, 5: Üniversite)

Tablo 3.15'e göre göç yaşamış öğrencilerin virgülü uygulama düzeyleri ortalamaları ile babaların eğitim durumları arasında anlamlı fark tespit edilmiştir $\left(F_{(4-209)}=6,624-p<0,05\right)$. Birimler arası farkların hangi gruplar arasında olduğunu tespit etmek amacıyla yapılan "Dunnett's $C$ " testinin sonuçlarına göre; babası okuma-yazma bilmeyen öğrencilerin ortalaması $(\bar{X}=1,00)$ ile babası ilkokul mezunu olanların ortalaması $(\bar{X}=1,51)$, babası ortaokul mezunu olanların ortalaması $\bar{X}=1,70$ ) ve babası lise mezunu olanların ortalaması $\bar{X}=1,85)$ ve babası üniversite mezunu olanların ortalaması $(\bar{X}=2,78)$ arasında anlamlı fark tespit edilmiştir. Ayrıca babası üniversite mezunu olanların ortalaması $(\bar{X}=2,78)$ ile; babası ilkokul mezunu olanların ortalaması $(\bar{X}$ $=1,51)$, babas1 ortaokul mezunu olanların ortalaması $(\bar{X}=1,70)$ ve babası lise mezunu olanların ortalamaları $(\bar{X}=1,85)$ arasında da anlamlı fark tespit edilmiştir.

Tablo 3.16. Göç yaşamış öğrencilerin kısa çizgiyi uygulama düzeyleri ile baba eğitim durumlarına göre "Tek Yönlü Anova" analizi sonuçları.

\begin{tabular}{|l|c|c|c|c|c|c|}
\hline $\begin{array}{c}\text { Varyansın } \\
\text { Kaynağı }\end{array}$ & $\begin{array}{c}\text { Kareler } \\
\text { Toplamı }\end{array}$ & sd & $\begin{array}{c}\text { Kareler } \\
\text { Ortalaması }\end{array}$ & F & P & Anlamlı Farklar \\
\hline Gruplararası & 8,585 & 4 & 2,146 & 2,296 & 0,060 & $1-5$ \\
\hline Gruplariçi & 195,341 & 209 & 0,935 & & & \\
\hline Toplam & 203,925 & 213 & & & & \\
\hline \multicolumn{7}{c|}{$\left[\mathrm{F}_{(4-209)}=2,296-\mathrm{p}>0,05\right]$. Hipotez Kabul Edilmemiştir. } \\
\hline
\end{tabular}

(1: Okuma-yazma yok, 2: İlkokul, 3: Ortaokul, 4: Lise, 5: Üniversite)

Tablo 3.16'da görüldüğü gibi göç yaşamış öğrencilerin kısa çizgiyi uygulama düzeyleri ortalamaları ile babaların eğitim durumları arasında anlamlı fark olduğu tespit edilmemiş̧ir. ( $\mathrm{F}_{(4-}$ $\left.{ }_{209)}=2,296-p>0,05\right)$. Babası okuma-yazma bilmeyen öğrencilerin ortalaması $(\bar{X}=1,50)$, babası ilkokul mezunu olanların ortalaması $(\bar{X}=1,92)$, babası ortaokul mezunu olanların ortalaması $(\bar{X}$ $=2,02)$, babası lise mezunu olanların ortalaması $(\bar{X}=2,21)$ ve babası üniversite mezunu olanların ortalamasi $(\bar{X}=2,78)$ 'dir.

Tablo 3.17. Göç yaşamış öğrencilerin soru işaretini uygulama düzeyleri ile baba eğitim durumlarına göre "Tek Yönlü Anova" analizi sonuçları.

\begin{tabular}{|c|c|c|c|c|c|c|}
\hline $\begin{array}{c}\text { Varyansın } \\
\text { Kaynağı }\end{array}$ & $\begin{array}{c}\text { Kareler } \\
\text { Toplamı }\end{array}$ & sd & $\begin{array}{c}\text { Kareler } \\
\text { Ortalaması }\end{array}$ & F & P & Anlamlı Farklar \\
\hline
\end{tabular}


Göç Yaşamış 6. Sınıf Öğrencileri’nin Noktalama İşaretlerini Uygulama Düzeylerinin İncelenmesi

\begin{tabular}{|l|c|c|c|c|c|c|}
\hline Gruplararas1 & 8,883 & 4 & 2,221 & 8,134 & 0,000 & $1-5,2-5,3-5,4-5$ \\
\hline Gruplariçi & 57,061 & 209 & 0,273 & & & \\
\hline Toplam & 65,944 & 213 & & & & \\
\hline \multicolumn{7}{c|}{$\left[\mathrm{F}_{(4-209)}=8,134-\mathrm{p}<0,05\right]$. Hipotez Kabul Edilmiştir. } \\
\hline
\end{tabular}

(1: Okuma-yazma yok, 2: İlkokul, 3: Ortaokul, 4: Lise, 5: Üniversite)

Tablo 3.17' ye göre göç yaşamış öğrencilerin soru işaretini uygulama düzeyleri ortalamaları ile babaların eğitim durumları arasında anlamlı fark olduğu tespit edilmiştir $\left(\mathrm{F}_{(4-209)}=8,134\right.$ $\mathrm{p}<0,05)$. Birimler arası farkların hangi gruplar arasında olduğunu tespit etmek amaciyla yapılan "Dunnett's $C$ " testinin sonuçlarına göre; babası üniversite mezunu olanların ortalaması ile, $(\bar{X}$ $=2,11)$ babası okuma-yazma bilmeyenlerin ortalaması $(\bar{X}=1,00)$, babası ilkokul mezunu olanların ortalaması $(\bar{X}=1,11)$, babası ortaokul mezunu olanların ortalaması $(\bar{X}=1,10)$ ve babası lise mezunu olanların ortalamaları $(\bar{X}=1,24)$ arasında anlamlı fark tespit edilmiştir.

Tablo 3.18. Göç yaşamış öğrencilerin noktalı virgülü uygulama düzeyleri ile baba eğitim durumlarına göre "Tek Yönlü Anova" analizi sonuçları.

\begin{tabular}{|l|c|c|c|c|c|c|}
\hline $\begin{array}{c}\text { Varyansın } \\
\text { Kaynağı }\end{array}$ & $\begin{array}{c}\text { Kareler } \\
\text { Toplamı }\end{array}$ & sd & $\begin{array}{c}\text { Kareler } \\
\text { Ortalaması }\end{array}$ & F & P & Anlamlı Farklar \\
\hline Gruplararası & 10,450 & 4 & 2,613 & 19,726 & 0,000 & $1-5,2-5,3-5,4-5$ \\
\hline Gruplariçi & 27,681 & 209 & 0,132 & & & \\
\hline Toplam & 38,131 & 213 & & & & \\
\hline \multicolumn{7}{c|}{$\left[\mathrm{F}_{(4-209)}=19,726-\mathrm{p}<0,05\right]$. Hipotez Kabul Edilmiştir. } \\
\hline
\end{tabular}

(1: Okuma-yazma yok, 2: İlkokul, 3: Ortaokul, 4: Lise, 5: Üniversite)

Tablo 3.18'e göre göç yaşamış öğrencilerin noktalı virgülü uygulama düzeyleri ortalamaları ile babaların eğitim durumları arasında anlamlı fark olduğu tespit edilmiştir $\left(\mathrm{F}_{(4-209)}=19,726\right.$ $\mathrm{p}<0,05)$. Birimler arası farkların hangi gruplar arasında olduğunu tespit etmek amacıyla yapılan "Dunnett's $C$ " testinin sonuçlarına göre; babası üniversite mezunu olanların ortalaması ile, $(\bar{X}$ $=2,11)$ babası okuma-yazma bilmeyenlerin ortalamas $(\bar{X}=1,00)$, babası ilkokul mezunu olanlarin ortalamas1 $(\bar{X}=1,04)$, babas1 ortaokul mezunu olanların ortalaması $(\bar{X}=1,00)$ ve babas1 lise mezunu olanların ortalamaları $(\bar{X}=1,18)$ arasında anlamlı fark tespit edilmiştir.

Tablo 3.19. Göç yaşamış öğrencilerin ünlem işaretini uygulama düzeyleri ile baba eğitim durumlarına göre "Tek Yönlü Anova" analizi sonuçları.

\begin{tabular}{|c|c|c|c|c|c|c|}
\hline $\begin{array}{c}\text { Varyansın } \\
\text { Kaynağı }\end{array}$ & $\begin{array}{l}\text { Kareler } \\
\text { Toplamı }\end{array}$ & sd & $\begin{array}{c}\text { Kareler } \\
\text { Ortalaması }\end{array}$ & $\mathbf{F}$ & $\mathbf{P}$ & Anlamlı Farklar \\
\hline Gruplararas1 & 8,380 & 4 & 2,095 & 26,213 & 0,000 & \multirow{2}{*}{$\begin{array}{llll}1-5 & 2-5 & 3-5 & 4-5\end{array}$} \\
\hline Gruplariçi & 16,704 & 209 & 0,080 & & & \\
\hline Toplam & 25,084 & 213 & & & & \\
\hline
\end{tabular}

(1: Okuma-yazma yok, 2: İlkokul, 3: Ortaokul, 4: Lise, 5: Üniversite) 
Tablo 3.19'a göre göç yaşamış öğrencilerin ünlem işaretini uygulama düzeyleri ortalamaları ile babaların eğitim durumları arasında anlamlı fark olduğu tespit edilmiştir $\left(\mathrm{F}_{(2-209)}=26,213\right.$ $\mathrm{p}<0,05)$. Birimler arası farkların hangi gruplar arasında olduğunu tespit etmek amaciyla yapılan "Dunnett's $C$ " testinin sonuçlarına göre; babası üniversite mezunu olanların ortalaması ile, $(\bar{X}$ $=2,00)$ babası okuma-yazma bilmeyenlerin ortalaması $(\bar{X}=1,00)$, babası ilkokul mezunu olanların ortalaması $(\bar{X}=1,00)$, babası ortaokul mezunu olanların ortalaması $(\bar{X}=1,07)$ ve babası lise mezunu olanların ortalamaları $(\bar{X}=2,00)$ arasında anlamlı fark tespit edilmiştir.

Tablo 3.20. Göç yaşamış öğrencilerin yay ayracı uygulama düzeyleri ile baba eğitim durumlarına göre "Tek-Yönlü Anova" analizi sonuçları.

\begin{tabular}{|l|c|c|c|c|c|c|}
\hline $\begin{array}{c}\text { Varyansın } \\
\text { Kaynağı }\end{array}$ & $\begin{array}{c}\text { Kareler } \\
\text { Toplamı }\end{array}$ & sd & $\begin{array}{c}\text { Kareler } \\
\text { Ortalaması }\end{array}$ & F & P & Anlamlı Farklar \\
\hline Gruplararası & 1,703 & 4 & 0,426 & 14,301 & 0,000 & $1-5,2-5,3-5,4-5$ \\
\hline Gruplariçi & 6,222 & 209 & 0,030 & & & \\
\hline Toplam & 7,925 & 213 & & & \\
\hline \multicolumn{7}{|c|}{$\left[\mathrm{F}_{(4-209)}=14,301-\mathrm{p}<0,05\right]$. Hipotez Kabul Edilmiştir. } \\
\hline
\end{tabular}

(1: Okuma-yazma yok, 2: İlkokul, 3: Ortaokul, 4: Lise, 5: Üniversite)

Tablo 3.20'ye göre göç yaşamış öğrencilerin ünlem işaretini uygulama düzeyleri ortalamaları ile babaların eğitim durumları arasında anlamlı fark olduğu tespit edilmiştir $\left(\mathrm{F}_{(4-209)}=14,301\right.$ $\mathrm{p}<0,05)$. Birimler arası farkların hangi gruplar arasında olduğunu tespit etmek amaciyla yapılan "Dunnett's $C$ " testinin sonuçlarına göre; babası üniversite mezunu olanların ortalaması ile, $(\bar{X}$ $=1,44)$ babası okuma-yazma bilmeyenlerin ortalaması $(\bar{X}=1,00)$, babası ilkokul mezunu olanların ortalamas $(\bar{X}=1,00)$, babası ortaokul mezunu olanların ortalaması $(\bar{X}=1,00)$ ve babası lise mezunu olanların ortalamaları $(X=1,00)$ arasında anlamlı fark tespit edilmiştir.

Tablo 3.21. Göç yaşamış öğrencilerin uzun çizgiyi uygulama düzeyleri ile baba eğitim durumuna göre "Tek-Yönlü Anova" analizi sonuçları.

\begin{tabular}{|l|c|c|c|c|c|c|}
\hline $\begin{array}{c}\text { Varyansın } \\
\text { Kaynağı }\end{array}$ & $\begin{array}{c}\text { Kareler } \\
\text { Toplamı }\end{array}$ & sd & $\begin{array}{c}\text { Kareler } \\
\text { Ortalaması }\end{array}$ & F & p & Anlamlı Farklar \\
\hline Gruplararası & 0,000 & 4 & 0,000 & & & \\
\hline Gruplariçi & 0,000 & 209 & 0,000 & & & \\
\hline Toplam & 0,000 & 213 & & & & \\
\hline
\end{tabular}

(1: Okuma-yazma yok, 2: İlkokul, 3: Ortaokul, 4: Lise, 5: Üniversite)

Anova testiyle uzun çizgiyi uygulama düzeylerinin ortalaması ile baba eğitim durumları arasında bir analiz yapılamamıştır.

Tablo 3.22. Göç yaşamış öğrencilerin eğik çizgiyi uygulama düzeyleri ile baba eğitim durumlarına göre "Tek Yönlü Anova" analizi sonuçları.

\begin{tabular}{|l|c|c|c|c|c|c|}
\hline \multicolumn{1}{|c|}{$\begin{array}{c}\text { Varyansın } \\
\text { Kaynağı }\end{array}$} & $\begin{array}{c}\text { Kareler } \\
\text { Toplamı }\end{array}$ & sd & $\begin{array}{c}\text { Kareler } \\
\text { Ortalaması }\end{array}$ & F & P & Anlamlı Farklar \\
\hline Gruplararası & 0,000 & 4 & 0,000 & & & \\
\hline Gruplariçi & 0,000 & 209 & 0,000 & & & \\
\hline Toplam & 0,000 & 213 & & & & \\
\hline
\end{tabular}


(1: Okuma-yazma yok, 2: İlkokul, 3: Ortaokul, 4: Lise, 5: Üniversite)

Eğik çizgi öğrenciler tarafından hiç kullanılmadığı için "Anova" testiyle eğik çizgiyi uygulama düzeyleri ortalamaları ile baba eğitim durumları arasında bir analiz yapılamamıştır.

Kesme işareti, iki nokta, üç nokta ve tırnak işaretini kullanım düzey ortalamalarının baba eğitim durumlarına göre "Tek-Yönlü Manova" analizi sonuçları aşağıdaki tablolarda verilmiş ve yorumlanmıştır.

Tablo 3.23. Kesme işareti, iki nokta, üç nokta ve tırnak işaretini kullanım düzey ortalamalarının baba eğitim durumlarına çoklu karşılaştırma test sonuçları

\begin{tabular}{|c|l|c|c|c|c|}
\hline \multicolumn{2}{|c|}{ Etki } & \multirow{2}{*}{ Değer } & \multirow{2}{*}{ F } & p & Kismi Eta \\
\cline { 5 - 6 } & & & & Kare \\
\hline Kesişme & Pillai's Trace & 0,800 & 205,408 & 0,000 & 0,800 \\
\hline & Wilks' Lambda & 0,200 & 205,408 & 0,000 & 0,800 \\
\hline & Hotelling's Trace & 3,989 & 205,408 & 0,000 & 0,800 \\
\hline & Roy's Largest Root & 3,989 & 205,408 & 0,000 & 0,800 \\
\hline & Pillai's Trace & 0,307 & 4,346 & 0,000 & 0,077 \\
\hline & Wilks' Lambda & 0,702 & 4,829 & 0,000 & 0,085 \\
\hline & Hotelling's Trace & 0,411 & 5,247 & 0,000 & 0,093 \\
\hline & Roy's Largest Root & 0,376 & 19,634 & 0,000 & 0,273 \\
\hline
\end{tabular}

Tablo 3.23, çoklu karşılaştırma test sonuçlarına göre göç yaşamış öğrencilerin baba eğitim durumuna göre kesme işaretini, iki nokta, üç nokta ve tırnak işaretini kullanım düzeyi ortalamaları arasında anlamlı farklılık olduğunu ortaya koymaktadır $(\Lambda=0,702, \mathrm{p}<0,05)$. Farklılıkların hangi gruplar arasında olduğunu incelemek amaciyla "Tek-Yönlü Manova" analiz sonuçları incelenmiştir.

Tablo 3.24. Kesme işareti, iki nokta, üç nokta ve tırnak işaretini kullanım düzey ortalamalarının baba eğitim durumlarına göre "Tek Yönlü Manova" analizi sonuçları

\begin{tabular}{|c|l|c|c|c|c|c|}
\hline \multirow{2}{*}{ Kaynak } & \multirow{2}{*}{ Bağımlı Değişken } & \multirow{2}{*}{ Sd } & Kareler & \multirow{2}{*}{ F } & \multirow{2}{*}{$\mathbf{p}$} & $\begin{array}{c}\text { Kısmi } \\
\text { Eta }\end{array}$ \\
& & & Ortalaması & & & Kare \\
\hline Düzeltilmiş & Kesme işareti & 4 & 2,260 & 4,851 & 0,001 & 0,085 \\
\hline Model & İki nokta & 4 & 2,167 & 5,049 & 0,001 & 0,088 \\
\hline & Üç nokta & 4 & 2,025 & 9,566 & 0,000 & 0,155 \\
\hline & Tirnak işareti & 4 & 4,375 & 13,286 & 0,000 & 0,203 \\
\hline Kesişme & Kesme işareti & 1 & 123,525 & 265,186 & 0,000 & 0,559 \\
\hline & İki nokta & 1 & 139,654 & 325,308 & 0,000 & 0,609 \\
\hline & Üç nokta & 1 & 96,679 & 456,761 & 0,000 & 0,686 \\
\hline & Tırnak işareti & 1 & 123,213 & 374,194 & 0,000 & 0,642 \\
\hline Baba Eğitim & Kesme işareti & 4 & 2,260 & 4,851 & 0,001 & 0,085 \\
\hline Durumu & İki nokta & 4 & 2,167 & 5,049 & 0,001 & 0,088 \\
\hline & Üç nokta & 4 & 2,025 & 9,566 & 0,000 & 0,155 \\
\hline & Tirnak işareti & 4 & 4,375 & 13,286 & 0,000 & 0,203 \\
\hline
\end{tabular}




\begin{tabular}{|l|l|l|l|l|l|l|}
\hline Hata & Kesme işareti & 209 & 0,466 & & & \\
\hline & İki nokta & 209 & 0,429 & & & \\
\hline & Üç nokta & 209 & 0,212 & & & \\
\hline & Tirnak işareti & 209 & 0,329 & & & \\
\hline Toplam & Kesme işareti & 214 & & & & \\
\hline & İki nokta & 214 & & & & \\
\hline & Üç nokta & 214 & & & & \\
\hline Düzeltilmiş & Tirnak işareti & 214 & & & & \\
\hline Toplam & Kesme işareti & 213 & & & & \\
\hline & İki nokta & 213 & & & & \\
\hline & Üç nokta & 213 & & & & \\
\hline
\end{tabular}

Tablo 3.24'e bakıldığında baba eğitim durumuna göre kesme işaretinin kullanım düzey ortalamalar1 arasında $\left(\mathrm{F}_{(4-209)}=4,851-\mathrm{p}<0,05\right)$, iki nokta kullanım düzey ortalamaları arasında $\left(\mathrm{F}_{(4-}\right.$ $209)=5,049-\mathrm{p}<0,05)$, üç nokta kullanım düzey ortalamaları arasında $\left(\mathrm{F}_{(4-209)}=9,566-\mathrm{p}<0,05\right)$, tırnak işaretini kullanım düzey ortalamaları arasında $\left(\mathrm{F}_{(3-209)}=13,286-\mathrm{p}<0,05\right)$ anlamlı fark tespit edilmiştir. $\mathrm{Bu}$ durum öğrencilerin baba eğitim durumları ile noktalama işaretlerini uygulama düzeyi arasında ilişki olduğunu göstermektedir. Baba eğitim durumu yükseldikçe işaretleri uygulama düzeyi de yükselmektedir.

Tablo 3.25. Kesme işareti, iki nokta, üç nokta ve tırnak işaretini kullanım düzey ortalamalarının baba eğitim durumlarına göre tanımlayıcı istatistikler

\begin{tabular}{|l|l|c|c|c|}
\hline & Baba Ĕgitim Durumu & Ortalama & $\begin{array}{c}\text { Standart } \\
\text { Sapma }\end{array}$ & $\begin{array}{c}\text { Örneklem } \\
\text { Büyüklüğü }\end{array}$ \\
\hline \multirow{4}{*}{ Kesme işareti } & Okuma-Yazma yok & 1,00 & 0,00 & 4,00 \\
\cline { 2 - 5 } & Ilkokul & 1,24 & 0,66 & 107,00 \\
\cline { 2 - 5 } & Ortaokul & 1,27 & 0,63 & 60,00 \\
\cline { 2 - 5 } & Lise & 1,44 & 0,79 & 34,00 \\
\cline { 2 - 5 } & Üniversite & 2,22 & 0,97 & 9,00 \\
\cline { 2 - 5 } & Toplam & 1,32 & 0,71 & 214,00 \\
\hline \multirow{5}{*}{ İki nokta } & Okuma-Yazma yok & 1,50 & 1,00 & 4,00 \\
\cline { 2 - 5 } & Illkokul & 1,24 & 0,63 & 107,00 \\
\cline { 2 - 5 } & Ortaokul & 1,25 & 0,57 & 60,00 \\
\cline { 2 - 5 } & Lise & 1,41 & 0,78 & 34,00 \\
\cline { 2 - 5 } & Üniversite & 2,22 & 0,83 & 9,00 \\
\cline { 2 - 5 } & Toplam & 1,32 & 0,68 & 214,00 \\
\hline \multirow{4}{*}{ U̧ç nokta } & Okuma-Yazma yok & 1,00 & 0,00 & 4,00 \\
\cline { 2 - 5 } & İlkokul & 1,04 & 0,27 & 107,00 \\
\cline { 2 - 5 } & Ortaokul & 1,07 & 0,36 & 60,00 \\
\cline { 2 - 5 } & Lise & 1,35 & 0,77 & 34,00 \\
\hline
\end{tabular}


Göç Yaşamış 6. Sınıf Öğrencileri’nin Noktalama İşaretlerini Uygulama Düzeylerinin İncelenmesi

\begin{tabular}{|l|l|l|c|c|}
\hline \multirow{4}{*}{} & Üniversite & 1,89 & 1,05 & 9,00 \\
\cline { 2 - 5 } & Toplam & 1,13 & 0,50 & 214,00 \\
\hline \multirow{4}{*}{ Tirnak işareti } & Okuma-Yazma yok & 1,00 & 0,00 & 4,00 \\
\cline { 2 - 5 } & İlkokul & 1,17 & 0,56 & 107,00 \\
\cline { 2 - 5 } & Ortaokul & 1,12 & 0,45 & 60,00 \\
\cline { 2 - 5 } & Lise & 1,32 & 0,73 & 34,00 \\
\cline { 2 - 5 } & Üniversite & 2,56 & 0,88 & 9,00 \\
\cline { 2 - 5 } & Toplam & 1,23 & 0,64 & 214,00 \\
\hline
\end{tabular}

Tablo 3.25 'te görüldüğü üzere babası üniversite mezunu olan öğrencilerin kesme işaretini uygulama düzeyi ortalaması $(\bar{X}=2,22)$ ile; babası okuma-yazma bilmeyen öğrencilerin ortalaması $(\bar{X}=1,00)$, babası ilkokul mezunu olan öğrencilerin ortalaması $(\bar{X}=1,24)$, babası ortaokul mezunu olan öğrencilerin ortalaması $(\bar{X}=1,27)$ ve babası lise mezunu olan öğrencilerin ortalaması $(\bar{X}=1,44)$ arasında anlamlı fark tespit edilmiştir.

Babası üniversite mezunu olan öğrencilerin iki nokta işaretini uygulama düzeyi ortalaması $(X=2,22)$ ile; babası okuma-yazma bilmeyen öğrencilerin ortalaması $(X=1,50)$, babası ilkokul mezunu olan öğrencilerin ortalaması $(\bar{X}=1,24)$, babası ortaokul mezunu olan öğrencilerin ortalaması $(\bar{X}=1,25)$ ve babası lise mezunu olan öğrencilerin ortalaması $(\bar{X}=1,41)$ arasında anlamlı fark tespit edilmiştir.

Üç nokta işaretinin ortalamaları ise şöyledir: Babası üniversite mezunu olan öğrencilerin üç nokta işaretini uygulama düzeyi ortalaması $(\bar{X}=1,89)$ ile; babası okuma-yazma bilmeyen öğrencilerin ortalaması $(\bar{X}=1,00)$, babası ilkokul mezunu olan öğrencilerin ortalaması $(\bar{X}=1,04)$ ve babası ortaokul mezunu olan öğrencilerin ortalaması $(\bar{X}=1,07)$ ve babası lise mezunu olan öğrencilerin ortalaması $(\bar{X}=1,35)$ arasında anlamlı fark tespit edilmiştir.

Son olarak babası üniversite mezunu olan öğrencilerin tırnak işaretini uygulama düzeyi ortalaması $(\bar{X}=2,56)$ ile; babası okuma-yazma bilmeyen öğrencilerin ortalaması $(\bar{X}=1,00)$, babası ilkokul mezunu olan öğrencilerin ortalaması $(\bar{X}=1,17)$, babası ortaokul mezunu olan öğrencilerin ortalaması $(\bar{X}=1,12)$ ve babası lise mezunu olan öğrencilerin ortalamaları arasında $(\bar{X}$ $=1,32$ ) anlamlı fark tespit edilmiştir.

Yukarıda verilen analiz sonuçlarına göre babaların eğitim durumu arttıkça çocukların noktalama işaretlerini uygulama düzeyi ortalamaları da artmaktadır. Bu durum ailelerin eğitim durumlarının çocukların eğitim ortamına yansımasının bir örneğidir.

\section{TARTIŞMA}

Göçün itici kuvvetlerinden ve sonuçlarından biri olan ailelerin düşük eğitim seviyesinin çocukların noktalama kurallarını uygulama düzeylerine etkisini inceleyen bu araştırmada birçok nitelikli sonuca ulaşılmıştır.

İş bulma amacıyla köyden kente göçen insanların eğitim seviyesinin düşük olması, sosyokültürel ve ekonomik açıdan birçok sorun ortaya çıkmaktadır Bu sorunlar da eğitim ortamına yansımaktadır. Bahsedilen problemlerin hiçbirinin olmadığı öğrencilerin bile noktalama işaretlerini uygulama düzeyi çok yüksek değildir. Bu konuda Uludağ'ın (2002) “İlköğretim İkinci Kademe Ögrrencileri'nin Yazım ve Noktalama Kurallarını Uygulama Beceri Düzeyi” adı makalesindeki "386 öğrencinin yazılı anlatım uygulamalarının incelenmesi sonucunda elde edilen veriler; ilköğretim ikinci kademede - özellikle 6. ve 7. sinıflarda- öğrenim gören öğrencilere yazılı anlatım içerisinde çok önemli yere sahip olan yazım kurallarını uygulama ve noktalama 
işaretlerini kullanma konularında gerekli becerilerin yeterli düzeyde kazandırılmadığını göstermekte ve bu da ögrencilerin yazılı anlatım çalışmalarında birçok hata yapmalarına neden olmaktadır" diyerek bu duruma dikkat çekmektedir.

Uygulama düzeyi genelde düşük olan noktalama işaretlerinin, öğrencilerin ailelerinin eğitim seviyesi düştükçe daha kötü bir tablo çizdiği görülmektedir. Uşaklı (2005), "İzmir'de Göç Alan Bölgeler'deki İlkögretim Okulları'nda (II) Türkçe Öğretiminde Karşılaşılan Sorunlar ve Çözüm Önerileri" adlı yüksek lisans tezinde "Sosyal tabaka, ögrencinin ögrrenme ve dil gelişiminde büyük bir rol oynamaktadır. Alt sosyo-ekonomik ailelerden gelen ögrencilerin Türkçe derslerinde orta ve yüksek sosyo-ekonomik ailelerden gelen ögrrencilere göre daha çok sorun yaşadıkları tespit edilmiştir. Bu da sosyal tabakanın ögrencinin öğrenme ve dil gelişimindeki anlamlı rolünü doğrulamaktadır" diyerek tespitlerimizi doğrulamaktadır.

Bu çalışmada, kullanım düzeyi ölçülen 13 noktalama işaretinin anne, baba eğitim durumlarına göre anlamlı farklılıklar gösterdiği tespit edilmiştir. Uzun çizgi sadece 1 kere kullanıldı̆̆ eğik çizgi ise hiç kullanılmadığ 1 için ölçmeye tabi tutulamamıştır.

Anne eğitim durumuna göre sadece nokta işaretinin uygulama düzeyi ortalamalarında anlamlı farklılık tespit edilememiştir. Virgül, kısa çizgi, soru işareti, noktalı virgül, ünlem, yay ayraç, kesme işareti, iki nokta, üç nokta, tırnak işareti uygulama düzeyi ortalamaları anne eğitim durumuna göre anlamlı farklılık göstermiştir. Annelerin eğitim seviyesi düştükçe çocukların noktalama işaretlerini uygulama düzeyi ortalamalarının da düştüğü görülmüştür. Eğitim seviyesi düştükçe okuma, anlama, yazma, yazılı metinlerle yüz yüze gelme oranı düşmekte ve bu durum annelerin dil becerilerine olumsuz yansımaktadır. Çocuğun her türlü gelişim alanında olduğu gibi dil gelişiminde de başrolü oynayan annelerin yetersiz dil becerileri çocukların da bu konuda yetersiz olmasina sebep olmaktadır.

Baba eğitim durumuna göre nokta ve kısa çizginin kullanım düzeyi ortalamalarında anlamlı farkl11ık tespit edilememiştir. Virgül, soru işareti, noktalı virgül, ünlem işareti, yay ayraç, kesme işareti, iki nokta, üç nokta, tırnak işareti uygulama düzeyi ortalamaları baba eğitim durumuna göre farkl1l1k göstermektedir. Baba eğitim seviyesi düştükçe bu işaretlerin uygulama düzeyi ortalamalarında da düşüş gözlenmektedir.

Anne eğitim durumuna göre tek noktalama işareti anlamlı fark göstermezken, baba eğitim durumuna göre iki noktalama işareti anlamlı fark göstermemektedir. Bu durumda annelerin eğitim durumunun çocukların noktalama işaretlerini uygulama düzeyi ortalamalarında daha etkili olduğu görülmektedir.

Göç yaşamış öğrencilerin annelerinin en yüksek eğitim seviyesi lise mezuniyeti iken, babalarında az da olsa üniversite mezuniyeti görülmektedir. Yukarıda da belirtildiği gibi anne eğitim durumu çocuk üzerinde doğrudan ve çok etkilidir. Annelerin babalardan daha düşük eğitim seviyesine sahip olmaları çocukların dil gelişiminde ve bununla ilişkili olarak noktalama işaretlerini uygulama düzeyi ortalamalarında önemli ölçüde etkindir.

Huber (2008) toplum dil bilimini tanımlarken "Dil yöresel farklıllklar gösterdiği gibi, mesleklere, cinsiyete, yaşa, katmana göre de ayrllklar gösterir. Sözü edilen etmenler nedeniyle de toplumsal gruplar oluşur, her toplumsal grup kendi dil kullanımını geliştirir" demektedir. Toplumsal grupları belirleyen etmenlerden biri de eğitim seviyesidir. Farklı eğitim seviyesine sahip toplumsal grupların dil kullanım becerileri de birbirinden farklıdır. Eğitim seviyesi ile dil kullanım becerileri doğru orantılıdır. Bu durum araştırmanın bulguları ile de doğrulanmıştır. 


\section{SONUÇ ve ÖNERILLER}

Araştırma bulgularına dayanarak aşağıdaki sonuçlara ulaşılmıştır.

1) Anne eğitim durumuna göre; virgül, kısa çizgi, soru işareti, noktalı virgül, ünlem işareti, yay ayraç, kesme işareti, iki nokta, üç nokta, tırnak işareti kullanım düzeyi ortalamalarında anlamlı fark tespit edilmiştir Annelerin eğitim seviyesi düştükçe bu işaretlerin kullanım düzeyi ortalamaları da düşmektedir. Anne eğitim durumu ile nokta işaretinin kullanım düzeyi ortalaması arasında anlamlı fark tespit edilememiştir.

2) Baba eğitim durumuna göre; virgül, soru işareti, noktalı virgül, ünlem işareti, yay ayraç, kesme işareti, iki nokta, üç nokta, tırnak işareti kullanım düzeyi ortalamaları anlamlı fark göstermektedir. Babaların eğitim seviyesi düştükçe bu işaretlerin kullanım düzeyi ortalamaları da düşmektedir. Baba eğitim durumu ile nokta ve kısa çizgi kullanım düzeyi ortalamaları arasında anlamlı fark tespit edilememiştir.

3) Eğik çizgi ve uzun çizgi kullanım sayısı yeterli olmadığından ölçüm yapılamamıştır.

Annelerin eğitim durumu babalara göre daha düşüktür. Anne eğitim durumuna göre bir işarette anlamlı fark tespit edilmezken, baba eğitim durumuna göre iki işarette anlamlı fark tespit edilememiştir. Bu durum annelerin eğitim seviyelerinin çocuklar üstünde babaların eğitim seviyesinden daha etkin olduğunu göstermektedir.

Ulaşılan bu sonuçlara dayanarak aşağıdaki önerilerde bulunulmuştur:

1) Göçle gelen ve sınırlı Türkçe yeterliliğine sahip olan öğrenciler için ihtiyaç analizi yapılmalıdır. $\mathrm{Bu}$ ihtiyaç analizi sayesinde öğrencilerin Türkçe yeterliliklerinin ne seviyede olduğu belirlenip bunun 1şığında onlara ayrı bir alternatif öğrenme programı uygulanması gerekmektedir. Bu işlemler için MEB bünyesinde program geliştirme uzmanlarından, Türkçe uzmanlarından, rehberlik uzmanlarından, ölçme-değerlendirme uzmanlarından oluşan özel bir komisyon hazırlanmalıdır.

2) Çocuklar yazım kurallarının önemini yazılı metinlerde, noktalama işaretlerinin önemini ise hem yazılı metinlerde hem de konuşma dilinde hissedebilirler. Bu konuda sadece öğretmenlerin hassasiyet göstermesi yeterli değildir. Ailelerin konuşma ve yazma konusunda duyarlı olması gerekmektedir. Göç alan bölgelerde ailelerin eğitim ve kültür seviyelerinin düşük olduğu bulgular kısmında verilmiştir. Bu noktada, göç alan bölgelerde ailelere yönelik de dil eğitimi verilmesi gereği ortaya çıkmaktadır. Okur-yazarlık kursları, dil eğitiminin önemi ile ilgili seminerler, aileleri de eğitimin içine katacak etkinlikler yapılması lazımdır.

3) Araştırmanın bulgularına dayanarak, göç yaşamış öğrencilerin annelerinin eğitim durumunun babalarının eğitim durumundan daha düşük olduğu ve annelerin eğitim durumunun düşük olmasının öğrencilerin noktalama işaretlerini uygulama düzeyi ortalamalarını babaların eğitim durumundan daha çok etkilediği tespit edilmiştir. Bu durumda annelerin eğitimine yönelik etkinliklerin artırılmasına öncelik verilmesi, annelerin eğitim ortamına daha fazla çekilmesi gerekmektedir.

4) Göç ile gelen öğrencileri kursa tabiî tutarak, farklı öğretim yöntem ve teknikleri kullanılarak, daha fazla ders tekrarı yapılarak diğer öğrenciler ile seviyelerinin birbirine yakın olması sağlanmalıdır. 


\section{KAYNAKÇA}

Akalın, M., Birinci, N., Ercilasun, B., Gülensoy, T., Korkmaz, Z., Parlatır, İ., \& Zülfikar, H. (2001). Türk Dili ve Kompozisyon Bilgileri. Ankara: Yarg1 Yayınları.

Aker, T., Ayata, B., Bay, A.,Buran, B., \& Özeren, M. (2002). "Zorunlu İç Göç: Ruhsal Toplumsal ve Sonuçları”. Anadolu Psikiyatri Dergisi, 3, 97-103.

Altunışık, R., Bayraktaroğlu, S., Coşkun, R., \& Yıldırım, E. (2010). Sosyal Bilimlerde Araştırma Yöntemleri. Adapazarı: Sakarya Yayıncılık.

Huber, E. (2008). Dilbilime Giriş. İstanbul: Multilingual Yabancı Dil Yayınları.

İmer, K. (1990). Dil ve Toplum. Ankara: Gündoğan Yayınları.

Karabuğa, H. (2011). Türkçe Öğretmeni Adaylarının Yazılı Anlatı Çalışmalarında Noktalama Işsaretlerini ve Yazım Kurallarını Kullanabilme Düzeyleri. Yayınlanmamış Yüksek Lisans Tezi. Abant İzzet Baysal Üniversitesi Sosyal Bilimler Enstitüsü, Bolu.

Karasar, N. (2003). Bilimsel Araştırma Yöntemi. Ankara: Nobel Yayın Dağıtım.

Kıran, Z. (1996). Dilbilim Akımları. Ankara: Onur Yayınları.

Özbay, M. (2011). "İlköğretim Türkçe Dersi (6-7-8. Sınıflar) Öğretim Programında Yazım ve Noktalama Kurallarının Sınıflara Göre Dağılımı”. Ed. M. Özbay. Yazma eğitimi, 185-193. Ankara: Pegem Akademi.

Şimşek, H., \& Yıldırım, A. (2008). Sosyal Bilimlerde Nitel Araştırma Yöntemleri. Ankara: Seçkin Yayıncilık.

Uludağ, E. (2002). "Erzincan: İlköğretim İkinci Kademe Öğrencilerinin Yazım ve Noktalama Kurallarını Uygulama Beceri Düzeyleri”. Erzincan Eğitim Fakültesi Dergisi, 4-1, 97-114.

Uşaklı, H. (2005). İmir İlinde Göç Alan Bölgelerdeki İlköğretim İlköğretim Okullarında (II) Türkçe Öğretiminde karşılaşılan Sorunlar ve Çözüm Önerileri. Yayımlanmamış Yüksek Lisans Tezi. Dokuz Eylül Üniversitesi Eğitim Bilimleri Enstitüsü, İzmir.

Vardar, B. (2002). Açıklamalı Dilbilim Terimleri Sözlüğü. İstanbul: Multilingual Yayınları.

Yazım Kılavuzu. (2009). Ankara: Türk Dil Kurumu Yayınları. 